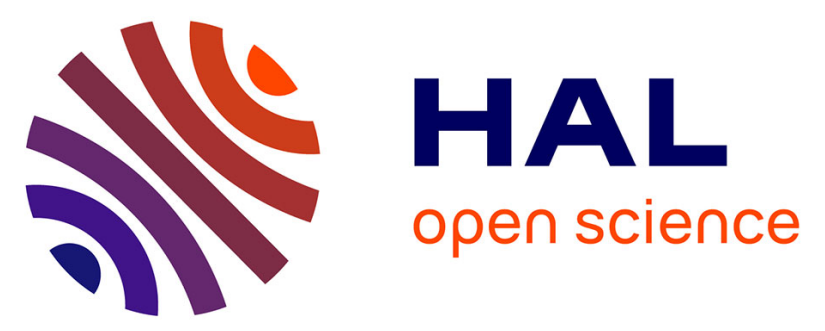

\title{
Co-processing of sulfidic mining wastes and metal-rich post-consumer wastes by biohydrometallurgy
} Anne-Gwenaëlle Guezennec, Kathy Bru, Jérôme Jacob, Patrick d'Hugues

\section{To cite this version:}

Anne-Gwenaëlle Guezennec, Kathy Bru, Jérôme Jacob, Patrick d'Hugues. Co-processing of sulfidic mining wastes and metal-rich post-consumer wastes by biohydrometallurgy. Minerals Engineering, 2015, pp.10.1016/j.mineng.2014.12.033. 10.1016/j.mineng.2014.12.033 . hal-01102658

\section{HAL Id: hal-01102658 https://hal-brgm.archives-ouvertes.fr/hal-01102658}

Submitted on 13 Jan 2015

HAL is a multi-disciplinary open access archive for the deposit and dissemination of scientific research documents, whether they are published or not. The documents may come from teaching and research institutions in France or abroad, or from public or private research centers.
L'archive ouverte pluridisciplinaire $\mathbf{H A L}$, est destinée au dépôt et à la diffusion de documents scientifiques de niveau recherche, publiés ou non, émanant des établissements d'enseignement et de recherche français ou étrangers, des laboratoires publics ou privés. 
Dear Author,

Please, note that changes made to the HTML content will be added to the article before publication, but are not reflected in this PDF.

Note also that this file should not be used for submitting corrections. 


\section{AUTHOR QUERY FORM}

\begin{tabular}{|l|l|l|}
\hline & Journal: MINE & Please e-mail or fax your responses and any corrections to: \\
& & E-mail: corrections.esch@elsevier.sps.co.in \\
\hline ELSEVIER & Article Number: 4565 & Fax: +31204852799 \\
\hline
\end{tabular}

Dear Author,

Please check your proof carefully and mark all corrections at the appropriate place in the proof (e.g., by using on-screen annotation in the PDF file) or compile them in a separate list. Note: if you opt to annotate the file with software other than Adobe Reader then please also highlight the appropriate place in the PDF file. To ensure fast publication of your paper please return your corrections within 48 hours.

For correction or revision of any artwork, please consult http://www.elsevier.com/artworkinstructions.

Any queries or remarks that have arisen during the processing of your manuscript are listed below and highlighted by flags in the proof. Click on the ' $Q$ ' link to go to the location in the proof.

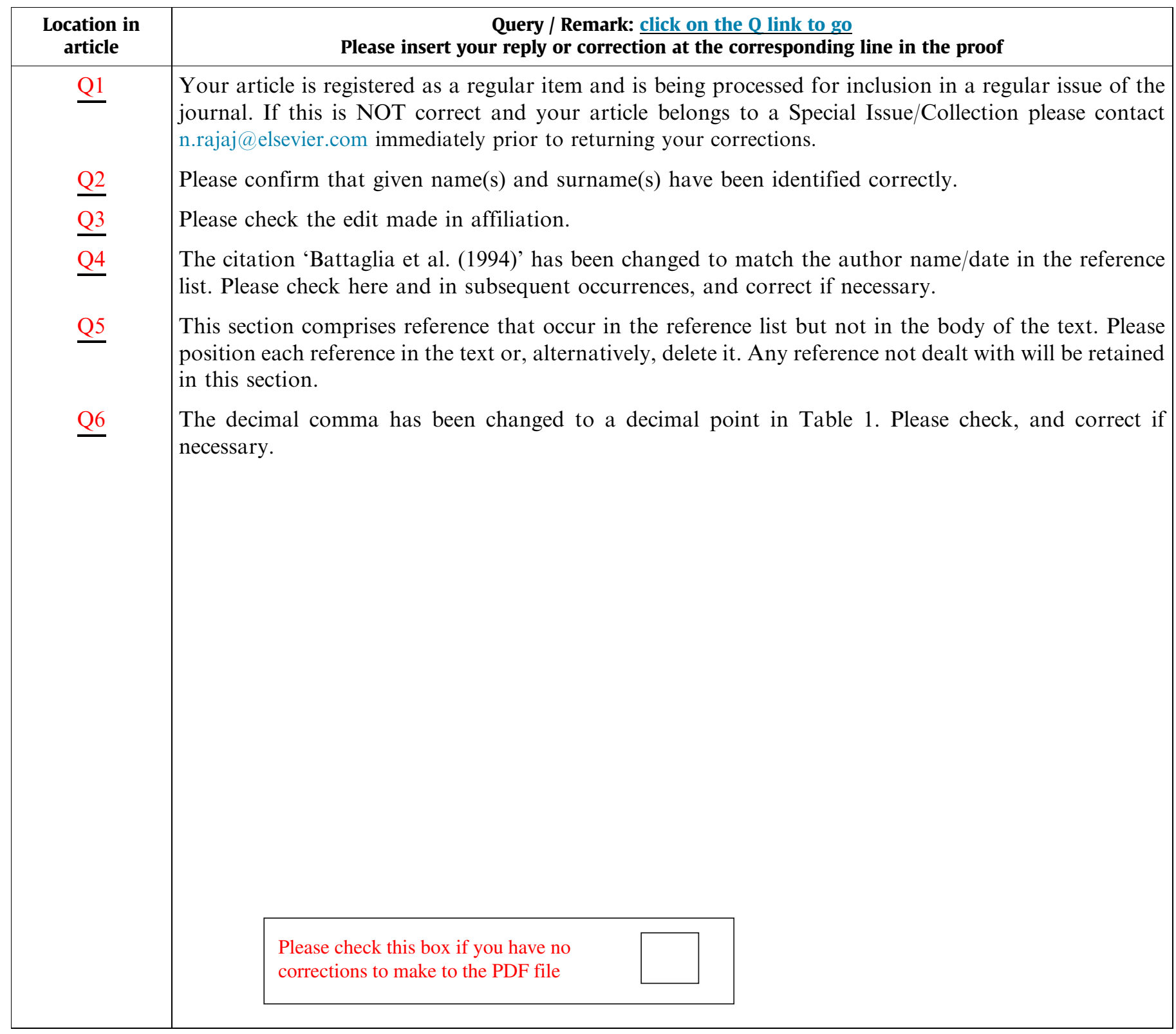

Thank you for your assistance. 


\section{Highlights}

- Bioleaching of sulfidic mining wastes enables to produce lixiviant solution that can be used further for e-wastes leaching. $\bullet$ Biological re-oxidation of iron greatly enhances metals dissolution kinetics and yields during PCBs leaching. • Copper extraction above $90 \%$ was achieved in $24 \mathrm{~h}$ of PCBs leaching. • Microbiologically assisted leaching of waste PCBs is a promising way for metals recycling. • Decoupling the lixiviant production from the leaching process enables to avoid toxicity issues. 


\title{
Co-processing of sulfidic mining wastes and metal-rich post-consumer
} wastes by biohydrometallurgy

\author{
7 Q2 Anne-Gwénaëlle Guezennec* ${ }_{\Lambda}^{*}$, Kathy Bru, Jérôme Jacob, Patrick d'Hugues,
}

8 Q3 BRGM, Water, Environment E Ecotechnologies Division, 3, av. Claude Guillemin, BP 36009, 45060 Orléans Cedex 2, France

\section{A R T I C L E I N F O}

Article history:

Received 7 August 2014

Revised 19 December 2014

Accepted 22 December 2014

Available online $\mathrm{xxx}$

\section{Keywords:}

Bioleaching

Mining wastes

WEEE

PCBs

Co-processing

\begin{abstract}
A B S T R A C T
The consequence of a strong economic growth in emerging countries combined with the rise of the world population is an increase in the demand for raw materials, leading to growing concern regarding their availability and the global efficiency of the supply chain. These tensions reinforce the need to associate the development of the recycling industry to the identification of new resources which could be used for the recovery of valuable materials. The purpose of this study is to develop a novel biological co-processing approach for the recovery of strategic metals in both sulfidic mining wastes and post-consumer wastes (WEEE). The principle of this treatment is based on two steps: mine wastes are biologically oxidized, resulting in the production of a ferric iron-sulfuric acid lixiviant solution which is used to leach base and other soluble metals contained in e-scraps. Batch tests were carried out using flotation tailings wastes containing $60 \%$ of pyrite and grinded Printed Circuit Boards (PCB $<750 \mu \mathrm{m}$ ) with a solid load of $2.5 \%$. Two series of tests were conducted in order to study the influence of the ferric iron concentration and of the bacterial activity on metals dissolution. Results showed that a higher ferric iron concentration led to an increase in the dissolution rate of copper which is the main metal contained in the PCBs. Moreover, a dissolution yield of $98.3 \%$ was reached for copper after 2 days when bacterial activity was observed, corresponding to an increase of about $20 \%$ compared to the tests without bacterial activity. Finally, this study highlights the importance of the availability of ferric iron and of the bacterial oxidation of ferrous iron for the feasibility of this bioleaching process dealing with the recycling of PCBs.
\end{abstract}

(c) 2014 Published by Elsevier Ltd.

\section{Introduction}

Among the different types of secondary post-consumption wastes, e-wastes represent the fastest growing and most problematic waste stream in the world. In the EU, 9.7 million tons were produced in 2009 and this is estimated to grow to a projected 12.3 million tons per year by 2020 (Huisman et al., 2008). Recovering metals from e-waste is potentially more energy efficient than mining raw material. However, they are highly complex in terms of structure and composition as very little consideration is given to end-of-life reprocessing during the design and construction of electronic goods. As a result it is not always possible to feed such waste into conventional recycling streams. Many of the metals on the "criticality" list are found in significant quantities in ewastes (EU, 2014). The majority of the value in e-waste is in the printed circuit boards (PCBs). On average $90 \%$ of the intrinsic economic value of PCBs is in the precious metals that they contain (Cui and Zhang, 2008). They also contain some critical metals such as

\footnotetext{
* Corresponding author. Tel.: +33 (0) 238643136 .

E-mail address: a.guezennec@brgm.fr (A.-G. Guezennec).
}

gallium. 65\% of the world's gallium production ends up in PCBs and no current process for its recovery exists. Copper is also very important: it is much more abundant in e-wastes and PCBs than the higher value metals, that is why its recovery and recycling are crucial given the increasing scarcity and complexity of copper ore.

Pyrometallurgy is the traditional choice for metal refining from processed (usually upgraded) e-waste, resulting in the production of precious metal-bearing copper bullion (Tuncuk et al., 2012). It can be done within existing smelters treating mineral concentrates, where e-waste may be combined (10-15\%) with a copper concentrate (Cui and Zhang, 2008). However, it is energy intensive and requires a relatively high grade feed material, and the ceramics from e-waste contribute to increase the final slag volume. Compared to pyrometallurgy, hydrometallurgical processes offer relatively low capital cost and are particularly suitable for small-scale installations (Tuncuk et al., 2012). An added advantage is their flexibility, offering a possibility for selective extraction of base and precious metals of interest in e-waste and PCBs. Since major metals exist in their elemental or alloy form in PCBs, their hydrometallurgical extraction has been tested 
using various oxidants (lixiviants; hydrogen peroxide, oxygen, ferric iron, etc.) under acidic $\left(\mathrm{HCl}, \mathrm{H}_{2} \mathrm{SO}_{4}, \mathrm{HNO}_{3}\right.$ etc.) or ammoniacal and chloride leaching environments (Quinet et al., 2005; Deveci et al., 2010; Huang et al., 2009; Kasper et al., 2011; Tuncuk et al., 2012). These studies have shown a different degree of base and precious metals recovery efficiency. However, these processes require the consumption of a high amount of chemicals. The use of microorganisms for the recovery of metals could then be an economic and environmental alternative. Biohydrometallurgy is an established technology for concentrates and mineral processing wastes. It has been recognized as a potential technology for the treatment of metallic wastes (Bryan et al., 2012). It has been used to recover copper and zinc from slags, galvanic sludge, fly ash and filter dust with recoveries close to $100 \%$ (Krebs et al., 2006). Studies into the bioleaching of e-waste have mainly involved the treatment of printed circuit boards (PCBs). The use of organic acids produced by various fungi or biogenic cyanide has been examined, particularly for the recovery of gold and other noble metals (Brandl et al., 2001; Faramarzi et al., 2004; Brandl et al., 2008; Chi et al., 2011). However, such approaches require the selective cultivation of specific microorganisms in circum-neutral media rich in organic substrates. This often requires aseptic growth conditions and is unlikely to be practical when treating large volumes of non-sterile e-wastes. Further, the majority of the cyanide produced is consumed by the copper which is in much higher concentrations relative to target metals such as gold. Therefore, the use of ferric iron and/or proton lixiviants produced by extreme acidophiles would be preferable and more practical. Indeed, there is no need for sterile conditions and culture media are relatively simple comprising key nutrients such as sources of nitrogen, potassium and phosphorus. In mineral bioleaching the source of iron and sulfur which are oxidized by the microbial community to produce the oxidizing acidic lixiviant solution is contained in pyrite or other sulfide minerals. In the current e-waste bioleaching practices, this source of iron and sulfur must be provided in addition to the nutritive medium. This is usually realized in the form of ferrous sulfate with acidity provided via $\mathrm{pH}$ control with sulfuric acid or through addition of elemental sulfur. The studies published so far (Zhu et al., 2011; Yang et al., 2009; Xiang et al., 2010; Liang et al., 2010; Karwowskaa et al., 2014; Hong and Valix, 2013; Ilyas et al., 2010; Cerruti et al., 1998) were carried out in shake flasks in liquid media containing ferrous iron, sometime amended with elemental sulfur and inoculated with pure or mixed cultures of iron- and sulfur-oxidizing microorganisms. Ground e-waste (usually PCBs) was either added immediately, in a one-step process, or following initial substrate oxidation (and thus lixiviant production) in an indirect two-step or multi-step process. The toxicity of the e-waste on the microorganisms has been shown to be the major problem preventing efficient leaching. Staggering the production of the lixiviant and the addition of the e-waste in a two-step process could then greatly increase leaching rates. Furthermore, $\mathrm{PCBs}$ are highly acid-consuming and require a high degree of $\mathrm{pH}$ modification to maintain an acidic environment necessary for the microbial action and metal solubility. The necessary addition of chemical products will increase the operating cost of such processes.

In addition to deposits of secondary post-consumer wastes (the classical target of the urban mining concept), old waste deposits related to past mining and metallurgical activities can also be significant reserves of valuable base or strategic metals as well as mineral substances. Before the 20th century, only a single or, at best, a couple of metals were extracted from any given mine. The other elements were either not detected by contemporary analytical methodology or considered as mineralogical "exotica". As demonstrated by European FP7 research project ProMine (http:// ptrarc.gtk.fi/ProMine/default.aspx) these types of mining and metallurgical residues contain not only rare and precious metals but also appreciable amounts of "residual" base metals $(\mathrm{Cu}, \mathrm{Ni}, \mathrm{Zn}$, Co...) which must not be neglected in today's context of resource scarcity and the environmental management of post mining activities.

While current laboratory-scale studies provide evidence that biohydrometallurgical reprocessing of e-wastes and mining wastes are technically possible, the wider economics of such type of processes are unlikely to be favorable with the current state-of-theart and the competition with "classical" pyro and hydro options. Using an industrial ecology approach and including the potential costs associated with the "no action scenario" in terms of waste management, a co-processing concept was envisaged.

The purpose of this study is therefore to develop a novel biological co-processing approach for the recovery of strategic metals in both sulfidic mining wastes and post-consumer wastes (e-scraps). The principle of this treatment is based on two steps: mine wastes are biologically oxidized, resulting in the production of a ferric iron-sulfuric acid lixiviant solution which is used to leach base and other soluble metals contained in e-scraps. By decoupling lixiviant production from PCB leaching in a two-step process, it is assumed that issues of toxicity will be avoided.

Bioleaching batch tests were performed using flotation tailings wastes containing $60 \%$ of pyrite in a first step, and, in a second step, grinded Printed Circuit Boards $(\mathrm{PCB}<750 \mu \mathrm{m})$ with the lixiviant produced by the bioleaching of the sulfidic wastes. The results were compared to those obtained in abiotic conditions using a synthetic leaching solution instead of a solution produced biologically.

\section{Materials and methods}

\subsection{Wastes}

The mining wastes used in this study are flotation tailings mainly composed of pyrite (60\%). They contain also cobalt $(0.06 \%)$, copper $(0.19 \%)$ and gold $(1 \mathrm{~g} / \mathrm{t})$. These wastes have been chosen for their high content of pyrite, which makes them particularly suitable for bioleaching. The electronic wastes are computer PCBs grinded first under $3 \mathrm{~mm}$ using a shear shredder and then under $750 \mu \mathrm{m}$ using a laboratory knife mill (Retsch, model SM2000).

\subsection{Bacterial culture and nutrients}

The tests were run using BRGM-KCC acidophilic and moderate thermophilic $\left(40^{\circ} \mathrm{C}\right)$ microbial consortium which has already been fully described (Battaglia et al., 1994; d'Hugues et al., 2003). The predominant organisms in the culture are affiliated to the genera Leptospirillum, Acidithiobacillus and Sulfobacillus. These bacteria are autotrophic and known as iron-oxidizer. They are also known for their tolerance to high concentrations of various metals espe-

\section{Table 1}

Q6 Average metal content in PCBs used for this study.

\begin{tabular}{|c|c|c|c|c|c|c|c|c|c|c|c|}
\hline $\mathrm{Cu}$ & $\mathrm{Fe}$ & $\mathrm{Ni}$ & $\mathrm{Pb}$ & $\mathrm{Zn}$ & Sn & $\mathrm{Ag}$ & $\mathrm{Au}$ & Pd & $\mathrm{Ga}$ & Co & Mo \\
\hline $\mathrm{g} / \mathrm{kg}$ & & & & & & $\mathrm{ppm}$ & & & & & \\
\hline 215.1 & 24.3 & 2.4 & 17.5 & 14.6 & 34.6 & 393.6 & 143.9 & 42.4 & 7.9 & 29.2 & 11.2 \\
\hline
\end{tabular}




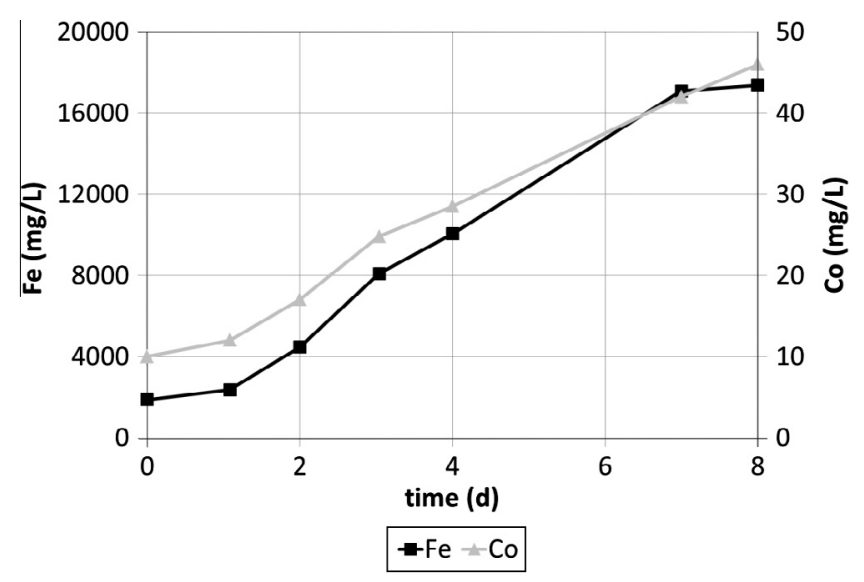

Fig. 1. Iron and cobalt concentration vs. time in solution during the bioleaching of the sulfidic mining wastes.

cially copper (Guezennec et al., 2014). The culture used as an inoculum originated from BRGM stock culture, stored at $-80^{\circ} \mathrm{C}$. The culture was subcultured several times in batch mode and on pyrite from $2 \mathrm{~mL}$ up to $2 \mathrm{~L}$ prior to the beginning of the batch test.

The culture was grown in a nutrient medium called " $0 \mathrm{Km}$ " medium. It is a modified " $9 \mathrm{~K}$ " medium (9 K without iron, "m" indicating modification of the basal salts) and was optimized for bacterial growth on cobaltiferous pyrite. Its standard composition is the following: $\left(\mathrm{NH}_{4}\right)_{2} \mathrm{SO}_{4}, 3.70 \mathrm{~g} \mathrm{~L}^{-1} ; \mathrm{H}_{3} \mathrm{PO}_{4}, 0.80 \mathrm{~g} \mathrm{~L}^{-1} ; \mathrm{MgSO}_{4} \cdot 7 \mathrm{H}_{2} \mathrm{O}$, $0.52 \mathrm{~g} \mathrm{~L}^{-1} ; \mathrm{KOH}, 0.48 \mathrm{~g} \mathrm{~L}^{-1}$.

\subsection{Metal content in solid fractions}

The metal content of initial PCBs and of leached residues was determined using an analytical procedure derived from standard NF EN 13657. The size of the PCBs particles after comminution is one of the main issues that must be encountered in PCBs analysis. The size of the samples must be sufficient to avoid uncertainties linked to the sampling representativeness. The analytical procedure was tested using several amounts of comminuted PCBs ( $1 \mathrm{~g}$, $3 \mathrm{~g}$ and $5 \mathrm{~g}$ ). From the results (data not shown) samples of $3 \mathrm{~g}$ were finally selected for the following of the study. The quartered samples of $3 \mathrm{~g}$ of materials (comminuted PCBs or leached residue) were dissolved in aqua regia using a closed system with reflow to avoid reagents losses. The contact time between the samples and aqua regia was about $24 \mathrm{~h}$ at room temperature and then $2 \mathrm{~h}$ at $200{ }^{\circ} \mathrm{C}$. After cooling, samples were carefully filtered and weighed. The insoluble portion indicates ceramic and polymers. The leached portion represents the soluble metals and was analyzed by inductively coupled plasma optical emission spectrometry (ICP-OES) and atomic adsorption spectrometry (AAS). The analyzed metals were: copper, iron, nickel, lead, zinc, tin, silver, gold, palladium, gallium, cobalt and molybdenum. The final solid residues were also characterized using optical microscopy as well as Scanning Electron Microscopy to check the presence of undissolved metals, which was not the case. The average metal content of PCBs samples used in this study is given in Table 1 .

\subsection{Laboratory apparatus}

\subsubsection{Bioleaching of mining wastes}

Bioleaching of the mining wastes was performed in order to produce the lixiviant solution used for the biotic leaching of PCBs. The tests were carried out in batch mode using $2 \mathrm{~L}$ laboratory scale glass reactors thermostated at $40{ }^{\circ} \mathrm{C}$. The reactors were baffled; the agitation was performed using a dual impeller system consisting of a standard 6-blade flat Rushton turbine in combination with a 6blade $45^{\circ}$ axial flow impeller. The impeller speed was set at $400 \mathrm{rpm}$. Air $\left(120 \mathrm{~L} \mathrm{~h}^{-1}\right)$ enriched with $\mathrm{CO}_{2}$ (1\%) was injected beneath the impeller at the bottom of the reactor via a stainlesssteel pipe. The tests were run in triplicate at $10 \%(\mathrm{w} / \mathrm{w})$ pulp density and the inoculation was performed by adding $200 \mathrm{~mL}$ of the BRGM-KCC culture in each reactor. When the $\mathrm{Fe}^{3+}$ concentration in the pregnant leach solution (PLS) reached the targeted value, reactors agitation and aeration were stopped. After natural decantation (around $12 \mathrm{~h}$ ) the supernatant solution was filtered at $0.65 \mu \mathrm{m}$ to remove particles while enabling bacteria to remain in the solution. This solution was then used as lixiviant solution for the biotic treatment of PCBs.

\subsubsection{PCBs leaching}

Two series of PCBs leaching tests were performed in batch conditions using comminuted samples of PCBs with a solid load of $2.5 \%$.

2.4.2.1. 1st series of PCBs leaching tests. The aim of the first series of experiments was to test the influence of initial $\mathrm{Fe}^{3+}$ concentration as well as the type of lixiviant solutions (biological or chemical) on the PCBs leaching. For this purpose, the experiments were carried out in $500 \mathrm{~mL}$ Erlenmeyer flasks containing $10 \mathrm{~g}$ of comminuted PCBs and $400 \mathrm{~mL}$ of the biogenic lixiviant solution produced from the bioleaching of mining wastes (biotic tests) or $400 \mathrm{~mL}$ of a synthetic lixiviant solution (abiotic tests). For the biotic tests, two concentrations of $\mathrm{Fe}^{3+}$ were tested: $11 \mathrm{~g} \mathrm{~L}^{-1}$ and $18 \mathrm{~g} \mathrm{~L}^{-1}$. The initial $\mathrm{pH}$ of the lixiviant solution was respectively 1.12 and 1.19 , the initial Eh being respectively 862 and $826 \mathrm{mV}$ (SHE). The synthetic solution was prepared by mixing deionized water with $\mathrm{Fe}_{2}\left(\mathrm{SO}_{4}\right)_{3}$, $7 \mathrm{H}_{2} \mathrm{O}$ salt in order to have a concentration of $\mathrm{Fe}^{3+}$ of about $18 \mathrm{~g} \mathrm{~L}^{-1}$. The initial $\mathrm{pH}$ of the synthetic solution was 1.38 and the initial Eh was $914 \mathrm{mV}$ (SHE). Biotic and abiotic tests were carried out in triplicate at ambient temperature and under magnetic stirring. Plastic paraffin film was used for sealing the Erlenmeyer flasks in order to prevent excessive evaporation.

2.4.2.2. 2nd series of PCBs leaching tests. The aim of the second series of experiments was to enhance the bacterial activity during PCBs leaching by providing bacteria with more appropriate conditions (i.e. temperature and oxygen transfer) and to compare the results with those obtained in the first series of PCBs leaching experiments. The tests were carried out in duplicate using laboratory scale glass reactors containing $1 \mathrm{~L}$ of the biogenic lixiviant solution with a $\mathrm{Fe}^{3+}$ concentration of $18 \mathrm{~g} \mathrm{~L}^{-1}$ and $26 \mathrm{~g}$ of PCBs. The agitation device used in these tests had the same characteristics as the one described for the production of the lixiviant solution. The initial $\mathrm{pH}$ of the lixiviant solution was 0.90 and the initial Eh was

Table 2

Characteristics of the biological lixiviant solutions.

\begin{tabular}{|c|c|c|c|c|c|c|c|c|c|}
\hline Type of PCB leaching test & $\mathrm{pH}$ & Eh (SHE) mV & $\mathrm{Fe}_{\text {tot }} \mathrm{mg} \mathrm{L}^{-1}$ & $\mathrm{Fe}^{2+} \mathrm{mg} \mathrm{L}^{-1}$ & $\mathrm{Cu}^{2+} \mathrm{mg} \mathrm{L}^{-1}$ & $\mathrm{Ni}^{2+} \mathrm{mg} \mathrm{L}^{-1}$ & $\mathrm{~Pb}^{2+} \mathrm{mg} \mathrm{L}^{-1}$ & $\mathrm{Zn}^{2+} \mathrm{mg} \mathrm{L}^{-1}$ & $\mathrm{Co}^{2+} \mathrm{mg} \mathrm{L}^{-1}$ \\
\hline \multirow[t]{2}{*}{ Erlenmeyer flasks $(500 \mathrm{~mL})$} & 1.1 & 862 & 10966 & 8 & 109 & 8.5 & 1.5 & 6.4 & 28 \\
\hline & 1.2 & 826 & 18145 & 42 & 135 & 16 & 6 & 11 & 45 \\
\hline Reactor (1 L) & 0.9 & 800 & 18430 & 151 & 112 & 14.7 & 5.9 & 15 & 46 \\
\hline
\end{tabular}


A.-G. Guezennec et al./Minerals Engineering $x x x(2015) x x x-x x x$

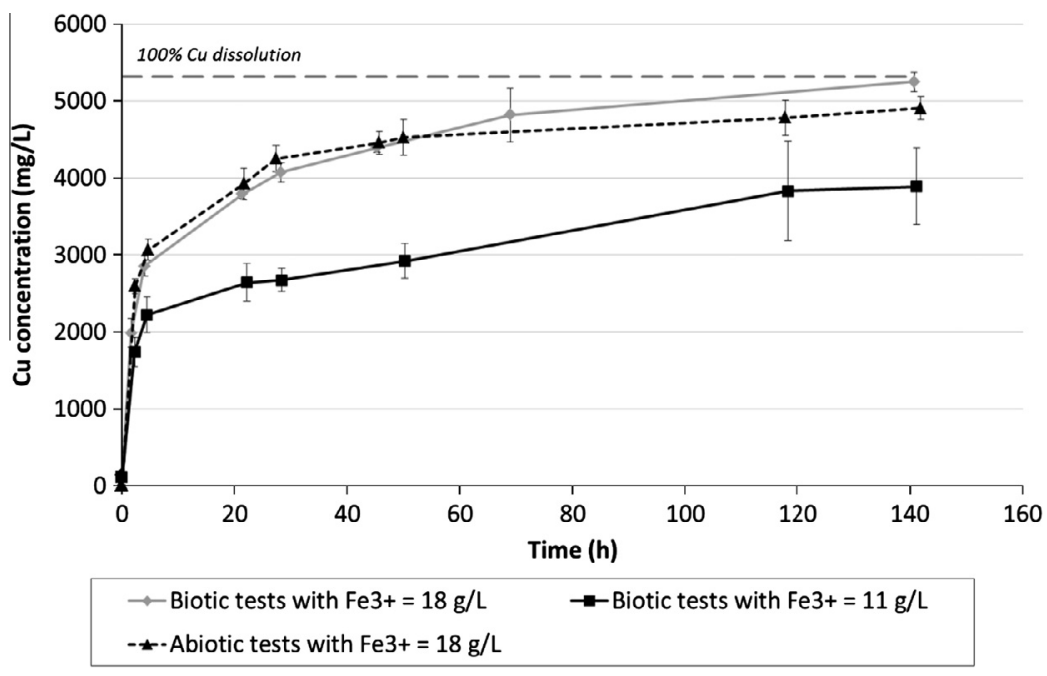

Fig. 2. $\mathrm{Cu}^{2+}$ concentration vs. time during biotic and abiotic leaching of PCBs in Erlenmeyer flasks.

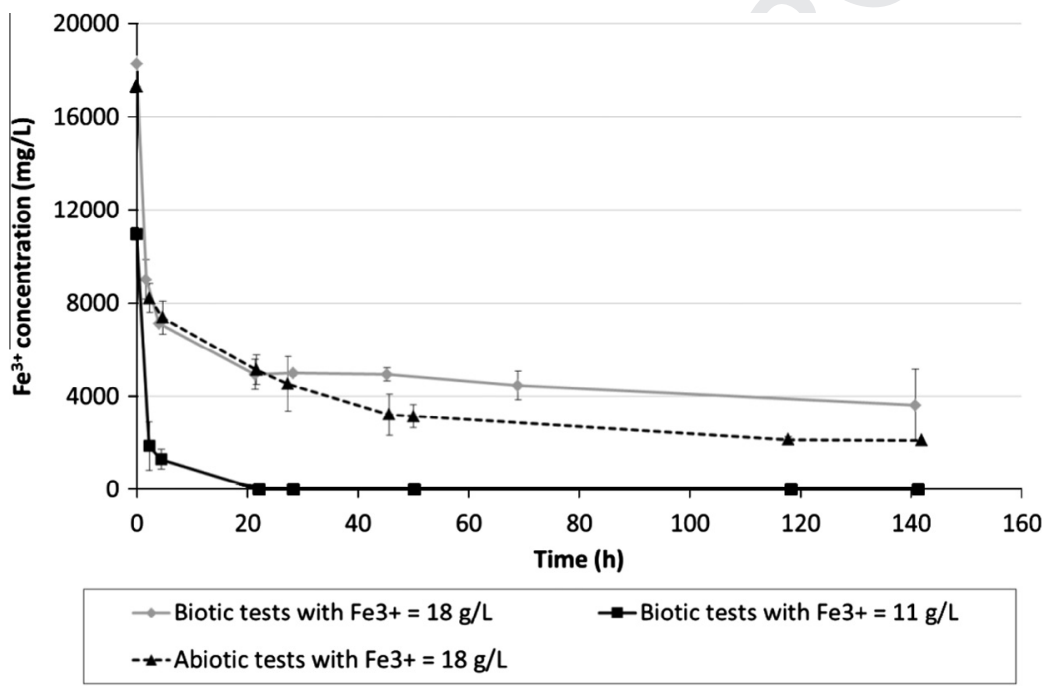

Fig. 3. $\mathrm{Fe}^{3+}$ concentration vs. time during biotic and abiotic leaching of PCBs in Erlenmeyer flasks.

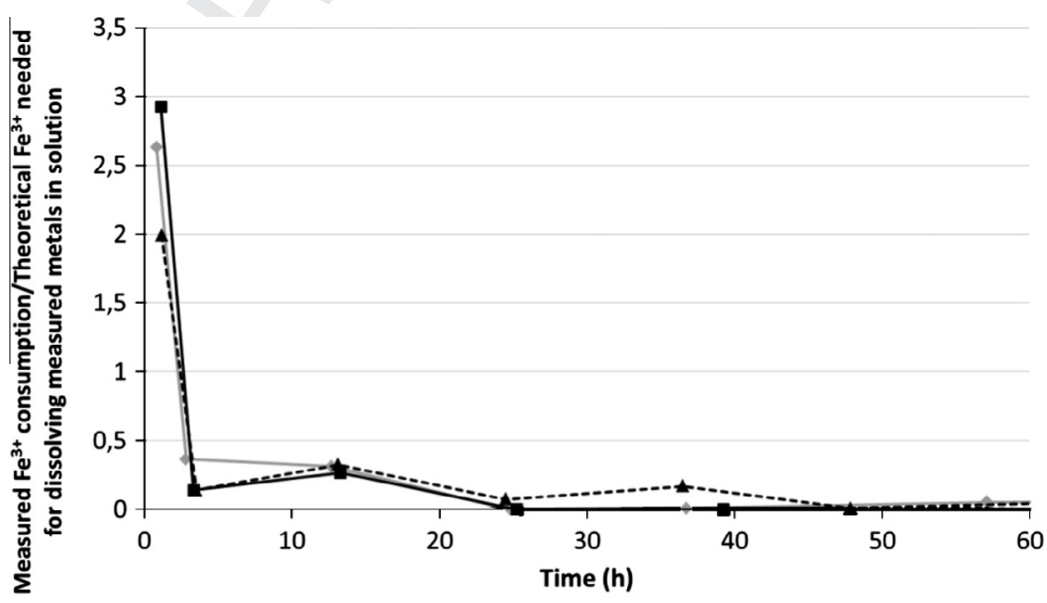

$\rightarrow$ Biotic tests with Fe3+ $=18 \mathrm{~g} / \mathrm{L}$

$\rightarrow$ Biotic tests with Fe3+=11 g/L

- -Abiotic tests with $\mathrm{Fe} 3+=18 \mathrm{~g} / \mathrm{L}$

Fig. 4. Ratio "Measured $\mathrm{Fe}^{3+}$ consumption/Theoretical $\mathrm{Fe}^{3+}$ needed for dissolving measured metals in solution" vs. time during biotic and abiotic leaching of PCBs. 
$800 \mathrm{mV}$ (SHE). The temperature of the reactors was maintained at $40{ }^{\circ} \mathrm{C}$ and the air flow rate was set at $0.5 \mathrm{~L} / \mathrm{h}$.

\subsection{Reactor monitoring}

Each type of reactors was monitored regularly for temperature, $\mathrm{pH}$ (adjusted below 1.8 by adding $\mathrm{H}_{2} \mathrm{SO}_{4}(96 \%)$ ) and redox potential. Several samples of solution were taken and filtered at $0.45 \mu \mathrm{m}$ in order to monitor the concentrations of $\mathrm{Fe}, \mathrm{Cu}, \mathrm{Ni}, \mathrm{Zn}$, $\mathrm{Pb}$ and $\mathrm{Co}$ (measured by $\mathrm{AAS}$ ) and of $\mathrm{Fe}^{2+}$ (determined by titration using cerium(IV) sulfate). Bacterial cells were counted regularly in biotic slurry samples. The leach residue was collected at the end of each batch test and analyzed using the procedure described in Section 2.3. The final liquor of the biotic tests was also analyzed by ICP-OES to determine Sn, Au, Ag, Ga, Mo and Pd final concentrations. These data were used further for the calculation of mass balance and metal dissolution yields.

\section{Results}

\subsection{Production of the lixiviant solution by bioleaching of sulfidic mining wastes}

Fe and Co concentration follow-up during the bioleaching of the sulfidic mining waste is shown in Fig. 1. The operating conditions were not optimized since the objective of these tests was only to produce lixiviant solution, but the curve is similar to the one obtained in previous study using KCC-BRGM microbial consortium on this pyritic waste with first a lag phase of one day, and then a regular increase of metal content. Experiments were stopped when the Fe concentration in the solution reached the targeted value: 11 or $18 \mathrm{~g} \mathrm{~L}^{-1}$. These values were chosen by calculating the stoichiometric amount of oxidant $\left(\mathrm{Fe}^{3+}\right)$ required to leach the metals contained in the PCBs. Indeed several authors showed that in presence of $\mathrm{Fe}^{3+}$, the dissolution of PCBs metals is governed by an oxidative mechanism based on the following equation (Yang et al., 2014; Zhu et al., 2011; Bas et al., 2013):

$\mathrm{M}^{0}+2 \mathrm{Fe}^{3+}=\mathrm{M}^{2+}+2 \mathrm{Fe}^{2+}$

Ferric iron in aqueous solution exhibits a standard reduction potential (Eh) as high as $+0.77 \mathrm{~V}$ and could readily solubilize base metals contained in electronic scraps. Knowing the content of $\mathrm{Cu}, \mathrm{Ni}, \mathrm{Zn}$, $\mathrm{Pb}, \mathrm{Fe}$ and $\mathrm{Sn}$ in the PCBs it can be easily calculated from Eq. (1) that $\mathrm{Fe}^{3+}$ concentration of $11 \mathrm{~g} \mathrm{~L}^{-1}$ corresponds to a stoichiometric ratio of 1.2 and $18 \mathrm{~g} \mathrm{~L}^{-1}$ to a stoichiometric ratio of 2 .

The lixiviant solution obtained from the bioleaching of the sulfidic wastes is characterized by low $\mathrm{pH}(<1.3)$ and high redox

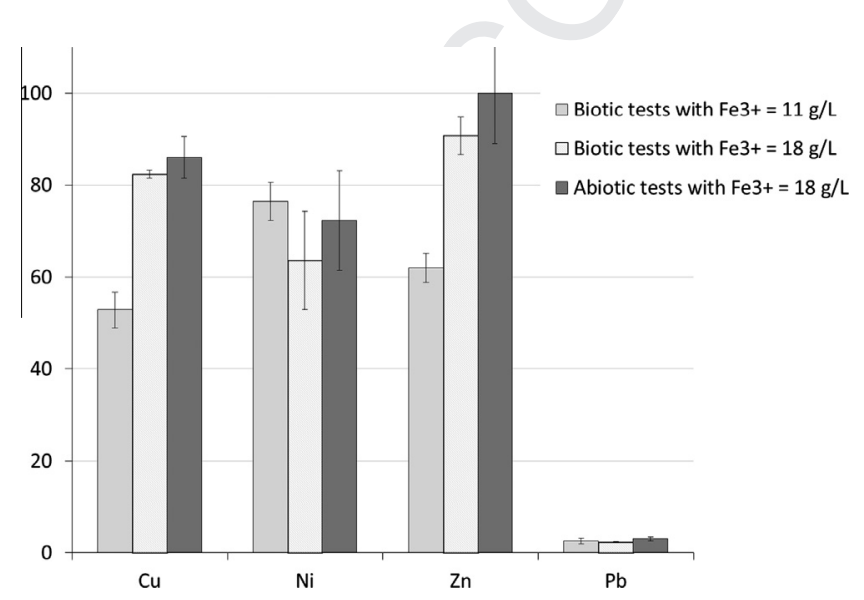

Fig. 5. Metal dissolution yields after 2 days of PCBs leaching in Erlenmeyer flasks. potential (800-862 mV), which indicates a good biological oxidizing activity (Table 2 ). This is confirmed by the low concentration of $\mathrm{Fe}^{2+}$ compared to total iron. The solution also contains small amounts of $\mathrm{Cu}, \mathrm{Ni}, \mathrm{Pb}, \mathrm{Zn}$ and $\mathrm{Co}$ (Table 2).

\subsection{PCBs leaching tests}

\subsubsection{Effects of $\mathrm{Fe}^{3+}$ concentration and of lixiviant solution type (chemical or biological) on leaching}

The first series of leaching tests aimed first at studying the influence of lixiviant solution production method (chemical or biological) on the metals dissolution by performing biotic PCBs leaching tests using the biogenic lixiviant solution obtained from the bioleaching of mining wastes and abiotic tests using a synthetic solution containing ferric iron and sulfuric acid. The concentration of $\mathrm{Fe}^{3+}$ was set to $18 \mathrm{~g} \mathrm{~L}^{-1}$ in both solutions. The 2nd aim was to study the influence of $\mathrm{Fe}^{3+}$ concentration on the metals dissolution. Therefore biotic tests were also carried out using the biogenic lixiviant solution with a ferric iron concentration of $11 \mathrm{~g} \mathrm{~L}^{-1}$. Biotic and abiotic experiments were performed in Erlenmeyer flasks at ambient temperature and without air injection.

The dissolved $\mathrm{Cu}^{2+}$ and $\mathrm{Fe}^{3+}$ concentrations were monitored with time (Figs. 2 and 3). Copper dissolution and ferric iron consumption are very similar in biotic and abiotic tests with an initial $\mathrm{Fe}^{3+}$ concentration of $18 \mathrm{~g} \mathrm{~L}^{-1}$. The $\mathrm{Cu}^{2+}$ concentration increased rapidly during the first $5 \mathrm{~h}$. A slower dissolution was then observed before the curve leveled off after $120 \mathrm{~h}$ with a final copper dissolution rate of about $96 \%$. Ferric iron follows an inverse trend with a sharp decrease in the first hours of the tests followed by a slower decrease afterwards. In biotic tests no re-oxidation of $\mathrm{Fe}^{2+}$ ions in $\mathrm{Fe}^{3+}$ ions was observed. Moreover, the number of bacterial cells displayed no significant changes during the biotic tests remaining to a level closed to $10^{8}$ bact $/ \mathrm{mL}$.

These results underline that there was no significant bacterial activity in tests performed with the biogenic lixiviant solution. This could be explained by the fact that the ambient temperature and the oxygen content in solution were too low for any activity of moderate thermophilic bacteria. Therefore, it can be concluded that, if carried out at ambient temperature, the ferric ion production method (chemical or biological) had no influence on the metals dissolution.

Regarding the influence of the $\mathrm{Fe}^{3+}$ concentration, Fig. 2 shows that higher $\mathrm{Fe}^{3+}$ concentration leads to increase the kinetics of the copper dissolution and the final recovery. Similar results were found by several authors (Yang et al., 2009; Zhu et al., 2011; Bas et al., 2013).

By comparing Figs. 2 and 3 it can be seen that in the biotic test with a $\mathrm{Fe}^{3+}$ concentration of $11 \mathrm{~g} \mathrm{~L}^{-1}$, Cu dissolution rate was lower than the consumption rate of $\mathrm{Fe}^{3+}$. Indeed, even if the initial $\mathrm{Fe}^{3+}$ concentration of $11 \mathrm{~g} \mathrm{~L}^{-1}$ corresponds to a stoichiometric ratio of 1.2 , all $\mathrm{Fe}^{3+}$ was consumed after one day whereas $\mathrm{Cu}$ dissolution rate was only about $50 \%$ at that time. In biotic and abiotic tests with a $\mathrm{Fe}^{3+}$ concentration of $18 \mathrm{~g} \mathrm{~L}^{-1}$, the consumption of $\mathrm{Fe}^{3+}$ is not complete: $\mathrm{Fe}^{3+}$ concentration decreases more slowly after $5 \mathrm{~h}$ of leaching and reaches a steady state even if all metals are not completely dissolved. This seems to indicate that ferric iron is no more involved in the leaching. One hypothesis could be that ferric iron forms complexes and is therefore not available for metals dissolution.

The ferric iron consumption was analyzed by calculating the ratio "Measured $\mathrm{Fe}^{3+}$ consumption/Theoretical $\mathrm{Fe}^{3+}$ needed for dissolving measured metals in solution" vs. time (see Fig. 4). This ratio take into account only the dissolution of $\mathrm{Cu}, \mathrm{Pb}, \mathrm{Ni}$ and $\mathrm{Zn}$ since they are the main metals contained in PCBs. In the first hours of leaching, this ratio is equal to 2 in the abiotic tests, which confirms that the metal dissolution corresponds to the oxidative process 


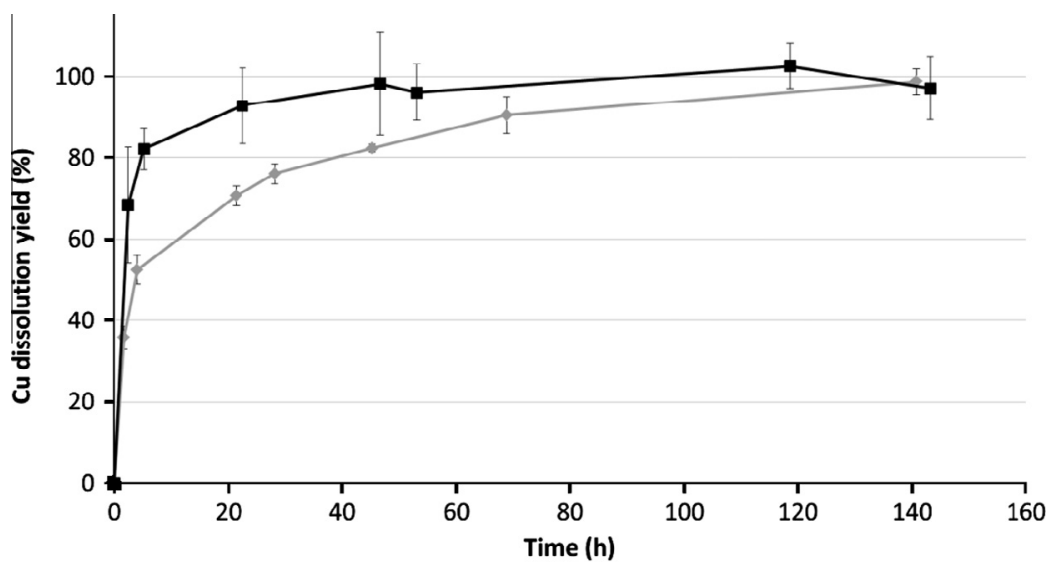

$\rightarrow$ biotic tests at ambient temperature (without bacterial activity)

$\rightarrow$-Biotic tests at $40^{\circ} \mathrm{C}$ (with bacterial activity)

Fig. 6. Evolution of $\mathrm{Cu}$ dissolution yields with time during biotic tests at $40{ }^{\circ} \mathrm{C}$ and at ambient temperature (initial $\mathrm{Fe}^{3+}=18 \mathrm{~g} \mathrm{~L}^{-1}$ ).

Table 3

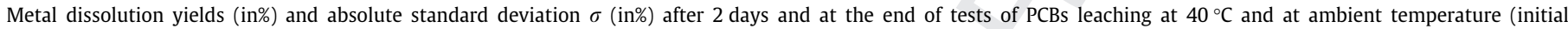
$\left.\mathrm{Fe}^{3+}=18 \mathrm{~g} \mathrm{~L}^{-1}\right)$.

\begin{tabular}{|c|c|c|c|c|}
\hline & \multicolumn{2}{|l|}{ After 2 days of leaching } & \multicolumn{2}{|c|}{ At the end of the leaching tests (about 6 days) } \\
\hline & $\begin{array}{l}\text { Biotic test at } 40^{\circ} \mathrm{C} \text { (with } \\
\text { bacterial activity) }\end{array}$ & $\begin{array}{l}\text { Biotic test at ambient temperature (without } \\
\text { bacterial activity) }\end{array}$ & $\begin{array}{l}\text { Biotic test at } 40^{\circ} \mathrm{C} \text { (with } \\
\text { bacterial activity) }\end{array}$ & $\begin{array}{l}\text { Biotic test at ambient temperature (without } \\
\text { bacterial activity) }\end{array}$ \\
\hline $\mathrm{Cu}$ & $98.3(\sigma=12.8)$ & $82.3(\sigma=0.9)$ & $97.7(\sigma=5.3)$ & $98.6(\sigma=3.2)$ \\
\hline $\mathrm{Ni}$ & $100(\sigma=2.8)$ & $63.5(\sigma=10.7)$ & $100(\sigma=5.9)$ & $84.3(\sigma=11.8)$ \\
\hline $\mathrm{Zn}$ & $95.3(\sigma=14.0)$ & $90.7(\sigma=4.1)$ & $95.2(\sigma=6.7)$ & $98.5(\sigma=5.8)$ \\
\hline $\mathrm{Pb}$ & $2.7(\sigma=0.1)$ & $2.3(\sigma=0.1)$ & $3.3(\sigma=0.1)$ & $2.6(\sigma=0.1)$ \\
\hline Ga & NA & NA & $68.6(\sigma=5.3)$ & $42.9(\sigma=7.4)$ \\
\hline Sn & NA & NA & $59.4(\sigma=1.6)$ & $6.8(\sigma=1.8)$ \\
\hline
\end{tabular}

NA: Not analyzed.

presented in Eq. (1). In biotic tests, whatever the $\mathrm{Fe}^{3+}$ concentration, the ratio is higher than 2 in the first hours, underlining the presence of other reactions consuming $\mathrm{Fe}^{3+}$. One hypothese which is reported by several authors (Yang et al., 2014; Zhu et al., 2011; Xiang et al., 2010; Vestola et al., 2010; Wang et al., 2009) could be the formation of jarosite precipitates (see Eqs. (2) and (3)), a reaction which is favored by the presence of ions such as $\mathrm{K}^{+}$or $\mathrm{NH}^{4+}$ brought by the nutrient medium:

$2 \mathrm{SO}_{4}^{2-}+3 \mathrm{Fe}^{3+}+6 \mathrm{H}_{2} \mathrm{O}+\mathrm{K}^{+}=\mathrm{KFe}_{3}\left(\mathrm{SO}_{4}\right)_{2}(\mathrm{OH})_{6}+6 \mathrm{H}^{+}$

$4 / 3 \mathrm{SO}_{4}^{2-}+2 \mathrm{Fe}^{3+}+4 \mathrm{H}_{2} \mathrm{O}+2 / 3 \mathrm{NH}_{4}^{+}$

$=2 / 3\left(\mathrm{NH}_{4}\right) \mathrm{Fe}_{3}\left(\mathrm{SO}_{4}\right)_{2}(\mathrm{OH})_{6}+4 \mathrm{H}^{+}$

After about $5 \mathrm{~h}$, this ratio falls under 0.5 meaning that metals dissolution not only occurs through the oxidative action of $\mathrm{Fe}^{3+}$ initially present in the flasks but also through other phenomena. For example, part of zero-valence metals could be directly leached out based on the following overall reaction, with $\mathrm{H}^{+}$coming from sulfuric acid:

$2 \mathrm{M}^{0}+4 \mathrm{H}^{+}+\mathrm{O}_{2} \rightarrow 2 \mathrm{M}^{2+}+2 \mathrm{H}_{2} \mathrm{O}$

As mentioned by several authors (Hong and Valix, 2013; Zhu et al., 2011; Yang et al., 2014; Bas et al., 2013) Eq. (4) has a low kinetics which could explain the decrease in copper dissolution rate after the rapid consumption of $\mathrm{Fe}^{3+}$ at the beginning of the leaching experiments.

The metal dissolution yields obtained after $48 \mathrm{~h}$ of leaching are summarized in Fig. 5. After 2 days, the Cu extraction was $82.5 \%$ in biotic tests with an initial $\mathrm{Fe}^{3+}$ concentration of $18 \mathrm{~g} \mathrm{~L}^{-1}, 86 \%$ in abiotic tests and $52.8 \%$ in biotic tests with an initial $\mathrm{Fe}^{3+}$ concentration of $11 \mathrm{~g} \mathrm{~L}^{-1}$. $\mathrm{Zn}$ showed the same behavior as $\mathrm{Cu}$ in all types of experiments. $\mathrm{Fe}^{3+}$ concentration seems to have no influence on the dissolution of $\mathrm{Ni}$. $\mathrm{Pb}$ dissolution yields are significantly lower than what can be expected given the $\mathrm{pH}$ and the redox of the solution, probably because of $\mathrm{Pb}$ precipitation phenomenon (Ilyas et al., 2010; Ilyas et al., 2013). Ilyas et al. (2013) reported in particular the formation of $\mathrm{PbSO}_{4}$ precipitates during $\mathrm{PCBs}$ bioleaching in shake flasks.

\subsubsection{Effects of bacterial activity on leaching}

Since no bacterial activity was detected in the first series of biotic tests, a second series of leaching tests was run in order to enhance bacterial activity and to favor biological oxidation of ferrous iron produced by the oxidative leaching of PCBs. The experiments were performed using the biogenic lixiviant solution $\left(\left[\mathrm{Fe}^{3+}\right]_{\mathrm{t} 0}=18 \mathrm{~g} \mathrm{~L}^{-1}\right)$ at $40^{\circ} \mathrm{C}$ which is known to be the optimal temperature for BRGM-KCC consortium. A small amount of air was injected $\left(0.5 \mathrm{~L} \mathrm{~h}^{-1}\right)$ in order to provide oxygen to bacteria. The results obtained were compared to those obtained with the biotic tests of the first series of PCBs leaching experiment run with the same biogenic lixiviant solution in shake flasks at ambient temperature. $\mathrm{Cu}$ concentration over time is shown in Fig. 6. A higher dissolution yield of copper is observed. After $4 \mathrm{~h}$ of leaching, $\mathrm{Cu}$ dissolution yield reached about $76 \%$ in these tests against $53 \%$ in the tests in flasks at ambient temperature. A complete extraction of copper, nickel and zinc is obtained after 2 days of leaching, whereas the extraction in flask tests is only $82.3 \%$ for $\mathrm{Cu}, 63.5 \%$ 


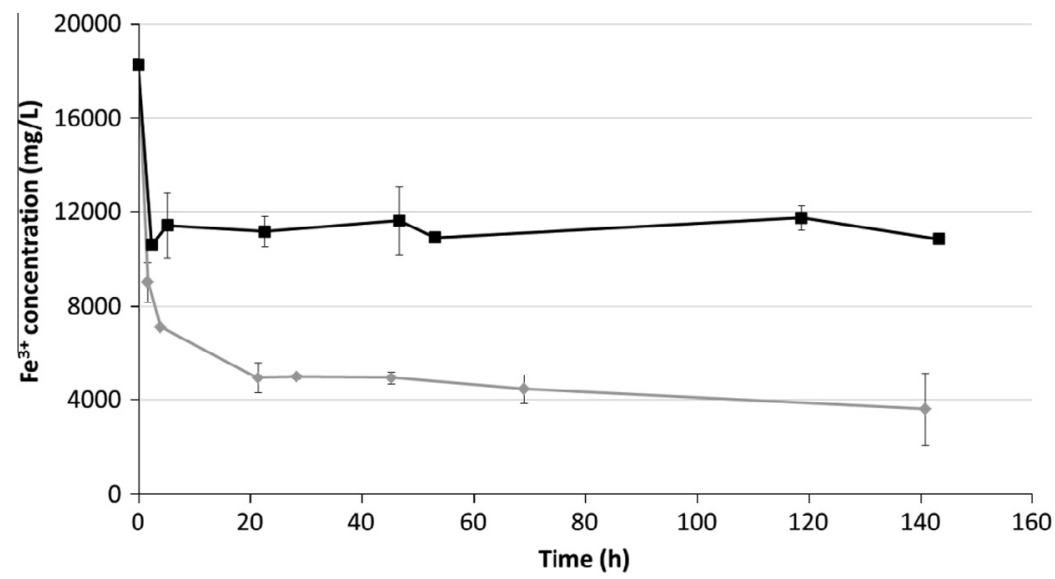

$\rightarrow$ Biotic tests at ambient temperature (without bacterial activity)

$\rightarrow$ Biotic tests at $40^{\circ} \mathrm{C}$ (with bacterial activity)

Fig. 7. $\mathrm{Fe}^{3+}$ concentration vs. time during biotic tests at $40{ }^{\circ} \mathrm{C}$ and at ambient temperature (initial $\mathrm{Fe}^{3+}=18 \mathrm{~g} \mathrm{~L}^{-1}$ ).

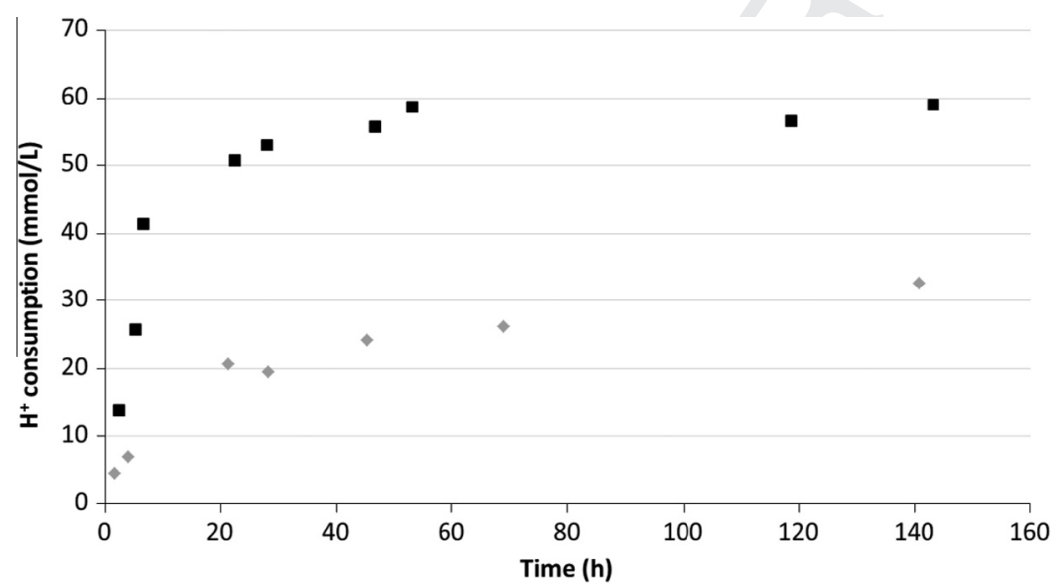

- Biotic tests without bacterial activity

- Biotic tests with bacterial activity

Fig. 8. $\mathrm{H}^{+}$consumption vs. time during biotic tests with and without bacterial activity (initial $\mathrm{Fe}^{3+}=18 \mathrm{~g} \mathrm{~L}^{-1}$ ).

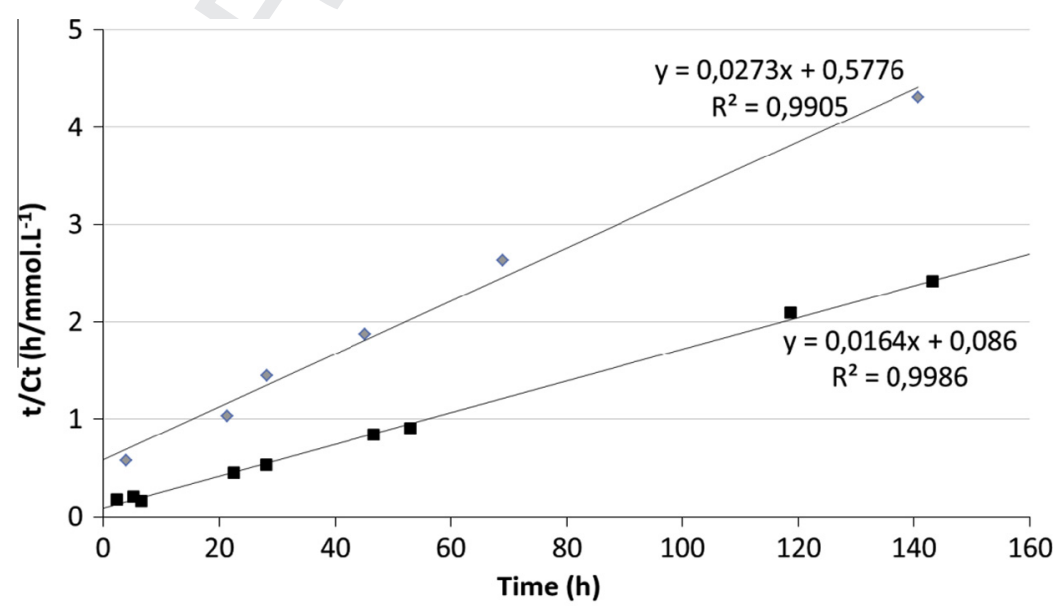

- Biotic tests without bacterial activity

- Biotic tests with bacterial activity

Fig. 9. Second-order model of $\mathrm{H}^{+}$consumption during biotic tests with and without bacterial activity (initial $\mathrm{Fe}^{3+}=18 \mathrm{~g} \mathrm{~L}^{-1}$ ). 
Table 4

Comparison between $\mathrm{Cu}$ extraction obtained by several authors and our results.

\begin{tabular}{|c|c|c|c|c|c|c|c|c|c|}
\hline & \multicolumn{5}{|l|}{ One-step leaching } & \multicolumn{4}{|c|}{ Two-step leaching } \\
\hline & Xiang et al. (2010) & Ilyas et al. (2007) & Ilyas et al. (2013) & Wang et al. (2009) & Zhu et al. (2011) & Yang & 1. (2009) & This & cudy \\
\hline PCB content $\left(\mathrm{g} \mathrm{L}^{-1}\right)$ & 20 & 10 & 100 & 7.8 & 8 & 25 & & 25 & \\
\hline Time (day) & 16 & 18 & 12 & 5 & 3 & 1 & 1.5 & 1 & 2 \\
\hline \% Diss. $\mathrm{Cu}$ & $95 \%$ & $74 \%$ & $90 \%$ & $70 \%$ & $92.9 \%$ & $90 \%$ & $100 \%$ & $93 \%$ & $99 \%$ \\
\hline
\end{tabular}

for $\mathrm{Ni}$ and $90.7 \%$ for $\mathrm{Zn}$ (Table 3). As previously observed, Pb dissolution yield is very low, probably due to phenomenon of precipitation. Results of metals extraction at the end of the tests (about 6 days) is also given in Table 3. After about 6 days, both cases have similar dissolution yields for $\mathrm{Cu}, \mathrm{Zn}$ and $\mathrm{Pb}$. Regarding extraction of $\mathrm{Ni}, \mathrm{Ga}, \mathrm{Sn}$ (both are only analyzed at the end of the experiments) after 6 days of leaching, higher values are reached in tests at $40{ }^{\circ} \mathrm{C}$; in particular, the $\mathrm{Sn}$ extraction rate is more than 8 times higher. As can be expected with an acid ferric lixiviant solution, no dissolution was obtained for $\mathrm{Au}, \mathrm{Ag}$, $\mathrm{Pd}$ and Mo (results not shown). Fig. 7 shows that this is correlated with a higher level of $\mathrm{Fe}^{3+}$ in solution. Indeed, even if both cases exhibit a drastic decrease of $\mathrm{Fe}^{3+}$ concentration in the first $2 \mathrm{~h}, \mathrm{Fe}^{3+}$ stabilizes then at about $11 \mathrm{~g} \mathrm{~L}^{-1}$ all along the tests at $40{ }^{\circ} \mathrm{C}$ whereas the concentration of $\mathrm{Fe}^{3+}$ decreases in the tests at ambient temperature. This difference is probably linked to the re-oxidation of ferrous iron by the oxidizing bacteria contained initially in the biological lixiviant solution according to the following equation:

$4 \mathrm{Fe}^{2+}+\mathrm{O}_{2}+4 \mathrm{H}^{+} \stackrel{\text { bacteria }}{\longrightarrow} 4 \mathrm{Fe}^{3+}+2 \mathrm{H}_{2} \mathrm{O}$

According to Bas et al. (2013), $\mathrm{Fe}^{2+}$ is the only energy-yielding substrate for bacteria to support the bacterial growth and activity in bioleaching process. A cycle between $\mathrm{Fe}^{3+}$ and $\mathrm{Fe}^{2+}$ is then built and metals are continually leached out. This could explain the increase in dissolution kinetics and in dissolution rates observed in tests with bacterial activity compared to the ones carried out at ambient temperature where no bacterial activity was detected. The ratio between FeIII and FeII in the solution ([FeIII]/[FeII]) is also an important parameter which must be encountered to interpret these results. In the test at $40{ }^{\circ} \mathrm{C}$ this ratio decreases to a value of 1.1 after $30 \mathrm{~min}$ and then increases to reach a value of 1.6 at the end of the experiments ( 7 days of leaching). In the tests at ambient temperatures this ratio decreases constantly to reach a value of 0.2 at the end of the experiments, which is much less favorable to metal leaching. These results highlight the central role of ferric iron in the metal dissolution process as well as the influence of the biological recycling of ferric iron on the leaching kinetics of PCBs.

\subsection{3. $\mathrm{H}^{+}$consumption during PCBs leaching}

Since the recycling of ferrous iron into ferric iron consumes $\mathrm{H}^{+}$ (see Eq. (5)), the consumption of protons during PCBs leaching and its influence on metal dissolution efficiency were examined. As indicated by Yang et al. (2014), the PCB leaching process can lead to several pathways of $\mathrm{H}^{+}$consumption: a direct $\mathrm{H}^{+}$consumption through reactions with substances of PCB such as alkaline substances, and an indirect $\mathrm{H}^{+}$consumption with bacterial oxidation of $\mathrm{Fe}^{3+} . \mathrm{H}^{+}$consumption over time is plotted in Fig. 8. Fig. 8 confirms that $\mathrm{H}^{+}$consumption is faster and higher in tests with bacterial oxidation of ferrous iron compared to the ones without this oxidation. Yang et al. (2014) suggested that $\mathrm{H}^{+}$consumption kinetics can be described by the following second-order kinetic model:

$\frac{t}{C_{t}}=\frac{t}{C_{e}}+\frac{1}{k_{2} C_{e}^{2}}$ where $t$ represents the time; $C_{t}$ represents the amount of $\mathrm{H}^{+}$consumption; $k_{2}$ represents the reaction rate constant of second-order kinetics; $C_{e}$ represents the total $\mathrm{H}^{+}$consumption in the whole process of bioleaching.

Fitting results of this second-order kinetic model are shown in Fig. 9. In both cases, the correlation coefficient is over 0.99 suggesting that the second-order kinetic model is able to adequately describe the progress of $\mathrm{H}^{+}$consumption during leaching. Calculation of the reaction rate constant $k_{2}$ gives $0.0031[\mathrm{mmol} / \mathrm{L}]^{-1}[\mathrm{~h}]^{-1}$ for tests with bacterial activity and $0.0013[\mathrm{mmol} / \mathrm{L}]^{-1}[\mathrm{~h}]^{-1}$ for tests without bacterial activity. Eq. (5) also allows evaluating the total $\mathrm{H}^{+}$consumption in the whole process of leaching and then the potential of metal dissolution rate. Potential value of the total $\mathrm{H}^{+}$consumption is strongly increased when bacteria are allowed to oxidize ferrous iron with a value of $60.9 \mathrm{mmol} \mathrm{L}^{-1}$ compared to $36.6 \mathrm{mmol} \mathrm{L}^{-1}$ for tests without bacterial activity, meaning that favorable conditions for bacterial oxidation of $\mathrm{Fe}^{2+}$ greatly enhances the overall extraction of metals. It must be noted also that given the importance of proton consumption during PCBs leaching, lixiviant solutions produced from the bioleaching of sulfidic mining wastes are not only interesting for their content in ferric iron but also because they provide high amounts of protons under the form of sulfuric acid.

\subsection{Comparison of this study with results from the literature}

$\mathrm{Cu}$ extraction obtained in the 2nd series of PCBs leaching experiments were compared to results from the literature. This comparison is not easy since experimental conditions are rather different. For example, the initial PCBs content in the reactor can vary from less than $1 \%$ to more than $10 \%$. The particle size distribution is also very different: PCBs are usually grinded under $250 \mu \mathrm{m}$; in some cases only the finest fraction is used in the tests. These factors can of course have a great influence on the results of leaching. It must be noted also that in most of the papers dedicated to PCBs bioleaching, experimental tests are performed in one step mode, which means that the lixiviant solution is not produced in a first reactor prior to PCBs leaching. Only a few papers propose PCBs leaching in two steps mode. As can be seen in Table 4, in the case of one-step leaching the final copper dissolution yield varies between $70 \%$ and $95 \%$ for a leaching time ranging from 3 to 18 . The two-steps mode enables to reach better kinetics and higher metal dissolution yield since the copper dissolution is almost complete in 2 days of leaching. Only Zhu et al. (2011) reached extraction yield above $90 \%$ after 3 days of one-step leaching, but initial PCBs content was 3 times smaller $\left(8 \mathrm{~g} \mathrm{~L}^{-1}\right.$ against $\left.25 \mathrm{~g} \mathrm{~L}^{-1}\right)$. In most of papers dealing with one-step leaching problems of metal toxicity impacting bacterial activity were mentioned to explain low leaching efficiency. The results obtained by Yang et al. (2009) in 2-steps mode using a culture of $A$. ferrooxidans are very similar to the results obtained in this study, which highlights the interest of this method of leaching. It confirms that decoupling lixiviant production and leaching process could limit problems of metal tolerance and thus greatly enhance leaching efficiency in terms of kinetics but also in terms of metals dissolution yields. 


\section{Conclusions}

The lixiviant solutions obtained from the bioleaching of sulfidic mining wastes using KCC-BRGM consortium showed a good performance for base metal recovery from waste PCBs $(\mathrm{Cu}, \mathrm{Ni}, \mathrm{Zn}$, $\mathrm{Pb}, \mathrm{Sn}, \mathrm{Ga}$ ). The tests were carried out using a two steps approach (bio-generation of the lixiviant oxidative solution/microbiologically assisted leaching of the PCBs). The results indicated that microbial assisted leaching was significantly more effective than a pure chemical leaching of PCBs. The extraction of metals was mainly accomplished indirectly through oxidation by ferric iron. The bacterial activity helped regenerating and maintaining a higher concentration of ferric iron in solution. The comparison with data from the literature is significantly encouraging since the rate and kinetics obtained in this study were much higher and quicker than those obtained in previous studies. It must be noted that in most of them, bioleaching was carried out using a one-step approach, which confirms the interest of decoupling the lixiviant production from the leaching process to avoid toxicity issues.

\section{Uncited reference}

Fujita et al. (2013).

\section{References}

Bas, A.D., Deveci, H., Yazici, E.Y., 2013. Bioleaching of copper from low grade scrap TV circuit boards using mesophilic bacteria. Hydrometallurgy 138, 65-70.

Battaglia, F., Morin, D., Ollivier, P., 1994. Dissolution of cobaltiferrous pyrite by Thiobacillus ferrooxidans and Thiobacillus thiooxidans - factors influencing bacterial leaching efficiency. J. Biotechnol. 32, 11-16.

Brandl, H., Bosshard, R., Wegmann, M., 2001. Computer-munching microbes: metal leaching from electronic scrap by bacteria and fungi. Hydrometallurgy 59 (2-3), 319-326.

Brandl, H., Lehmann, S., Faramazi, M.A., Martinelli, D., 2008. Biomobilization of silver, gold, and platinum from solid waste materials by $\mathrm{HCN}$-forming microorganisms. Hydrometallurgy 94 (1-4), 14-17.

Bryan, C.G., Watkin, E., McCredden, T., Wong, Z., Harrison, S., Kaksonen, A., 2012. From Wii to WEEE: the application of biohydrometallurgy to electronic wastes. Biohydromet '12, Falmouth, UK, June 18-20.

Cerruti, C., Curutchet, G., Donati, E., 1998. Bio-dissolution of spent nickel-cadmium batteries using Thiobacillus ferrooxidans. J. Biotechnol. 62, 209-219.

Chi, T.D., Lee, J., Pandey, B.D., Yoo, K., Jeong, J., 2011. Bioleaching of gold and copper from waste mobile phone PCBs by using a cyanogenic bacterium. Miner. Eng. 24 (11), 1219-1222.

Cui, J., Zhang, L., 2008. Metallurgical recovery of metals from electronic waste: a review. J. Hazard. Mater. 158 (2-3), 228-256.

Deveci, H., Yazıcı, E.Y., Aydın, U., Yazıcı, R., Akcil, A., 2010. Extraction of copper from scrap TV boards by sulphuric acid leaching under oxidizing conditions. In: Proceedings of Going Green-CARE.

d'Hugues, P., Battaglia-Brunet, F., Clarens, M., Morin, D. 2003. Microbial diversity of various metal-sulfides bioleaching cultures grown under different operating conditions using 16S-rDNA analysis. In: Tsezos, M., Remoudaki, E., Hatzikioseyian, A. (Eds.), International Biohydrometallurgy Symposium IBS 2003. Hellas, Athens, pp. 1313-1324.
EU 2014. REPORT ON CRITICAL RAW MATERIALS FOR THE EU. Report of the Ad hoc Working Group on defining critical raw materials, May 2014.

Faramarzi, M., Stagars, M., Pensini, E., Krebs, W., Brandl, H., 2004. Metal solubilization from metal-containing solid materials by cyanogenic Chromobacterium violaceum. J. Biotechnol. 113 (1-3), 321-326.

Fujita, T., Ono, H., Dodbiba, G., 2013. Recycling and evaluation of printed circuit board by physical separation and heat treatment. Proceedings Sardinia 2013, Fourteenth International Waste Management and Landfill Symposium, S. Margherita di Pula, Cagliari, Italy; 30 September - 4 October 2013.

Guezennec, A.G., Hanke, M., Chmielarz, A., Joulian, C., Ménard, Y., d'Hugues, P., 2014. Bio-hydrometallurgy: an alternative to pyrometallurgy for copper recovery in a polymineral concentrate. Proceedings of Hydrometallurgy 2014 Congress June 22-25, Victoria, Canada.

Hong, Y., Valix, M., 2013. Bioleaching of electronic waste using acidophilic sulfur oxidizing bacteria. J. Cleaner Product. 65, 465-472.

Huang, K., Guo, J., Xu, Z., 2009. Recycling of waste printed circuit boards: a review of current technologies and treatment status in China. J. Hazard. Mater. 164 (2-3), 399-408.

Huisman, J. et al., 2008. Review of Directive 2002/96 on Waste Electrical and Electronic Equipment (WEEE) Final Report, 2008. United Nations University, Bonn, Germany.

Ilyas, S., Anwar, M.A., Niazi, S.B., Ghauri, M.A., 2007. Bioleaching of metals from electronic scrap by moderately thermophilic acidophilic bacteria. Hydrometallurgy 88, 180-188.

Ilyas, S., Lee, J., Chi, R., 2013. Bioleaching of metals from electronic scrap and its potential for commercial exploitation. Hydrometallurgy 131-132, 138-143.

Ilyas, S., Ruan, C., Bhatti, H.N., Ghauri, M.A., Anwar, M.A., 2010. Column bioleaching of metals from electronic scrap. Hydrometallurgy 101, 135-140.

Karwowskaa, E., Andrzejewska-Morzucha, D., Łebkowskaa, M., Tabernackaa, A., Wojtkowskab, M., Telepkob, A., Konarzewskab, A., 2014. Bioleaching of metals from printed circuit boards supported with surfactant-producing bacteria. J. Hazard. Mater. 264, 203-210.

Kasper, A.C., Berselli, G.B.T., Freitas, B.D., Tenório, J.A.S., Bernardes, A.M., Veit, H.M., 2011. Printed wiring boards for mobile phones: characterization and recycling of copper. Waste Manage. 31 (12), 2536-2545

Krebs, W., Brombacher, C., Bosshard, P., Bachofen, R., Brandl, H., 2006. Microbial recovery of metals from solids. FEMS Microbiol. Rev. 20 (3-4), 605-617.

Liang, G., Mo, Y., Zhou, Q., 2010. Novel strategies of bioleaching metals from printed circuit boards (PCBs) in mixed cultivation of two acidophiles. Enzyme Microbial Technol. 47 (7), 322-326.

Quinet, P., Proost, J., Van Lierde, A., 2005. Recovery of precious metals from electronic scrap by hydrometallurgical processing routes. Miner. Metall. Process. 22 (1), 17-22.

Tuncuk, A., Stazib, V., Akcila, A., Yazicic, E.Y., Devecic, H., 2012. Aqueous metal recovery techniques from e-scrap: hydrometallurgy in recycling. Miner. Eng. 25, 28-37.

Vestola, E.A., Kuusenaho, M.K., Närhi, H.M., Tuovinen, O.H., Puhakka, J.A., Plumb, J.J., Kaksonen, A.H., 2010. Acid bioleaching of solid waste materials from copper, steel and recycling industries. Hydrometallurgy 103, 74-79.

Wang, J.W., Bai, J.F., Xu, J.Q., Liang, B., 2009. Bioleaching of metals from printed wire boards by Acidithiobacillus ferrooxidans and Acidithiobacillus thiooxidans and their mixture. J. Hazard. Mater. 172, 1100-1105.

Xiang, Y., Wua, P., Zhua, N., Zhang, T., Liu, W., Wu, J., Li, P., 2010. Bioleaching of copper from waste printed circuit boards by bacterial consortium enriched from acid mine drainage. J. Hazard. Mater. 184 (1-3), 812-818.

Yang, Y., Chen, S., Li, S., Chen, M., Chen, H., Liu, B., 2014. Bioleaching waste printed circuit boards by Acidithiobacillus ferrooxidans and its kinetics aspect. J. Biotechnol. 173, 24-30.

Yang, T., Xu, Z., Wen, J., Yang, L., 2009. Factors influencing bioleaching copper from waste printed circuit boards by Acidithiobacillus ferrooxidans. Hydrometallurgy $97(1-2), 29-32$

Zhu, N., Xiang, Y., Zhang, T., Wu, P., Dang, Z., Li, P., Wu, J., 2011. Bioleaching of metal concentrates of waste printed circuit boards by mixed culture of acidophilic bacteria. J. Hazard. Mater. 192 (2), 614-619. 